\title{
PROPERTIES AND COMPARISON OF PVD COATINGS
}

\author{
Ivan Mrkvica, Miroslav Neslušan, Robert Čep, Vojtěch Sléha
}

Preliminary notes

Development and application of new materials in mechanical engineering practice create a lot of questions concerning their technological application. This paper focuses on research problems related to the PVD coated cemented carbide. The theoretical part of the paper informs about principle of PVD coating technology and describes the arc evaporation method used for coating in greater detail. It also deals with coating materials and types, their properties, possible applications and finally principles of the experimental methods used for coatings testing are explained. In the experimental part of the paper, the measuring and testing procedures are described and the test results are listed. Adhesion and layer durability were compared by cutting inserts with different PVD - nanostructure and nanolayer coatings. The tests were carried out by milling of carbon engineering steel 1.1191 (C45), because this steel is widely used in many industrial applications and it is used as reference material too. In conclusion the testing results are evaluated on the basis of obtained information.

Keywords: adhesion; coating; layer durability; nanocomposite layers; PVD and ARC methods

\section{Svojstva i usporedba PVD slojeva premaza}

Razvoj i primjena novih materijala u strojarskoj praksi dovode do mnoštva pitanja u odnosu na njihovu tehnološku primjenu. Ovaj je rad usmjeren na istraživanje problema povezanih s cementiranim karbidom premazanim primjenom PVD (Physical Vapour Deposition) metode. U teorijskom dijelu rada upoznaje se PVD tehnologija nanošenja sloja i detaljnije opisuje metoda isparavanja luka. Opisuju se također materijali i vrste slojeva, njihova svojstva, moguće primjene i na kraju objašnjavaju načela eksperimentalnih metoda primijenjenih u ispitivanju slojeva. U eksperimentalnom dijelu rada opisuju se postupci mjerenja i ispitivanja te daju rezultati ispitivanja. Adhezija i trajnost slojeva uspoređeni su na izrezanim umetcima s različitim PVD - premazi s nanostrukturom i nanoslojem. Ispitivanja su provedena glodanjem ugljičnog čelika 1.1191 (C45) budući da se taj čelik uvelike rabi u mnogim industrijskim primjenama, a također i kao referentni material. Na kraju se ocjenjuju rezultati ispitivanja na temelju dobivenih podataka.

Ključneriječi: adhezija; nanosastavljeni slojevi; PVD i ARC metode; sloj premaza; trajnost sloja

\section{Introduction}

Protective cutting tool coating together with cutting material, tool geometry and cutting conditions has a significant effect on tool edge life [1] and surface integrity $[2,3]$, which are the sign of successful machining. The main method of cemented carbide tools coating, primarily by turning $[4,5]$, is CVD (Chemical Vapour Deposition) method with high process temperatures $\left(1000 \div 1200{ }^{\circ} \mathrm{C}\right.$ ). However, PVD (Physical Vapour Deposition) method is used increasingly. It is characterized by lower process temperatures (below 500 $\left.{ }^{\circ} \mathrm{C}\right)$. This method was originally developed for highspeed steel coating, where tool material structure can be thermally influenced due to high temperatures. Recently, there is a significant development of PVD coating methods and their applications even at the field of cemented carbide tools.

With PVD methods, coatings are produced at reduced pressure $(0,1 \div 1,0 \mathrm{~Pa})$ by particle (atoms, cluster of atoms) condensation. These particles are released from particle source (targets) using physical methods such as sputtering (by accelerated Ar ions generated in crossed electromagnetic field) or evaporation (inductively, by low-voltage arc, laser or electron beam) and some methods use even resistance heating [6].

Released particles are ionized, they react with vacuum chamber atmosphere consisting of inert plus reactive gases and they are accelerated by negative bias voltage (hundreds of volts) to the surface of substrate, where these ions create thin homogeneous coating (usually from 1 to $5 \mu \mathrm{m}$ ).

The disadvantages of all PVD methods are complex vacuum system and requirement of coated objects movement to guarantee uniform coating deposition over the entire surface and preventing the unwanted shadowing effect. On the other hand, PVD methods allow us to coat sharp edges with radius below $20 \mu \mathrm{m}$.

The coating material is evaporated from the electrodes by an arc and simultaneously ionized by it. Ionized material is accelerated to the tool surface by negative bias voltage, which is applied on it. On its way this material ionizes atoms of atmosphere (e.g. Ar, $\mathrm{N}_{2}$ ). deposited layer as the result of the surface reactions.

Low-voltage arc parameters are very interesting. Arc burns on the cathode surface at the cathode spot with $10 \mu \mathrm{m}$ diameter and reaches temperature around $15000{ }^{\circ} \mathrm{C}$. Under these conditions any electrically conductive material can be evaporated. The targets (evaporated material) have to be positioned closely to the coated objects and ionization level has to be high. This problem can be optimally solved by using rotary electrodes (ARC).

The internal arrangement of the coating chambers with rotary cylindrical electrodes has three possible variants, which differ from each other by an electrode positioning. It is possible to position them centrally (in the middle of a coating chamber) or laterally, for example in access door (LARC system - LAteral Rotating Cathodes). The last variant combines both previous electrode positions (CERC system - CEntral Rotating Cathode) - Fig. 1 .

Variable electric current values applied to the electrodes, together with the ratio between them, is possible to control stoichiometry, growth rate and roughness of layers without changing electrode material. Basic coating structures such as mono-, multi- and gradient layers, are prepared in this way. 


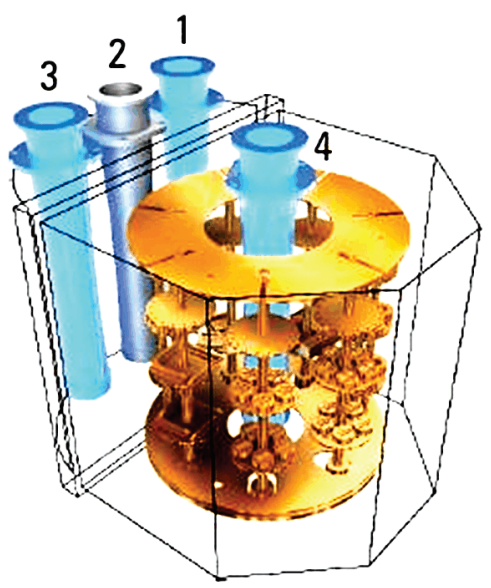

Figure 1 Scheme of PVD coating equipment with centrally and laterally positioned cathodes [7]

The statistics focused on the German market $[8 \div 10]$ show that there is a trend to replace TiN and TiCN layers by TiAlN. Vickers hardness of TiN layers comes up to $23 \mathrm{GPa}$ and its maximal working temperature is $600{ }^{\circ} \mathrm{C}$. The requirement for high abrasion resistance led to the development of very hard TiCN layers with hardness HV up to $35 \mathrm{GPa}$, but its maximal working temperature is only $450^{\circ} \mathrm{C}$. However, TiCN has favourable coefficient of friction, so even with lowered working temperature this material is difficult to replace in certain application areas $[11,12]$.

The third material group is based on TiAlN reaching hardness $\mathrm{HV}$ up to $33 \mathrm{GPa}$, together with possible working temperatures over $800{ }^{\circ} \mathrm{C}$. This meets the requirements of industrial applications for high abrasive resistance and chemical stability at high temperatures. The logical result of this is increased use of TiAlN in the industrial applications.

Certain TiAlN layers contain additional elements, such as $\mathrm{Cr}$, Y, Hf. These elements in small quantities positively affect the layer structure and improve its properties. The main objective is to achieve the productive machining requirements. It involves applications generating high heat or dry applications with ecological and economic benefits. This leads to development of coating systems with higher $\mathrm{Al}$ ratio than normally $(\mathrm{Ti}: \mathrm{Al}=50: 50)$. Very high $\mathrm{Al}$ ratio causes hardness reduction. There are physical limits for formation of hard cubic AlN structure, so the systems with ratio $\mathrm{Ti}: \mathrm{Al} \leq 35: 65$ are suitable for narrower application areas and become less stable.

The common TiAlN or AlTiN layers are inadequate to applications requiring high thermal and chemical stability. There is a growing effort to produce TiAlN layers with innovative structure modifications improving physico-mechanical properties: multilayers, gradient layers and nanostructured layers. The last mentioned group includes a special group of nanocomposite layers.

The multilayers in general develop cracks slowly and increase layer hardness. Simultaneously the structure of multilayeres allows to produce thicker layers than in case of the monolayers.

The gradient or nanogradient layers are systems with continuously changing hard components ratio (e.g. AlN). Higher $\mathrm{Al}$ ration near the layer surface secure high oxidation resistance while maintaining adequate hardness.
The nanolayers are multilayered systems with each individual layer thickness below $10 \mathrm{~nm}$. If these single layers have different physical properties and the interface between them is abrupt enough, then it is possible to find out the optimal layer period, which greatly increases hardness.

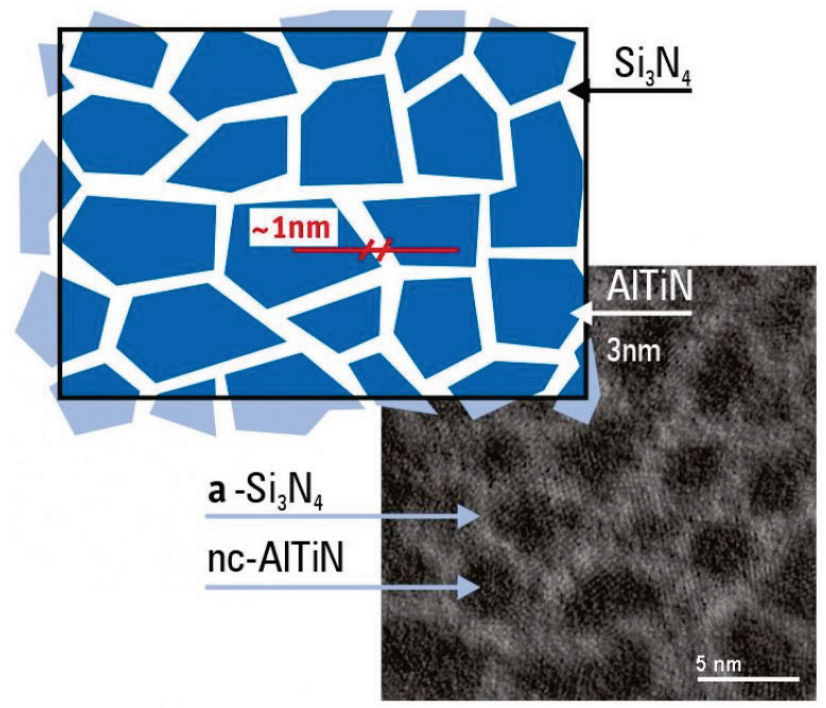

Figure 2 Nanocomposite layer - tiny crystals sized few nanometers in amorphous matrix (both phases are immiscible) [7]

Thanks to their structure, the nanocomposite layers are highly resistant to oxidation and they are thermally stable. Nanocomposites are represented by nc-(Ti1$\mathrm{xAlxN} / \mathrm{a}-\mathrm{Si}_{3} \mathrm{~N}_{4}$ ) layer. TiAlN is crystalline component and $\mathrm{Si}_{3} \mathrm{~N}_{4}$ is amorphous matrix, Fig. 2. This structure is among the hardest PVD coatings in the commercial sector, its hardness $\mathrm{HV}$ values go over $40 \mathrm{GPa}$.

CrAlN based layers are alternatives to TiAlN $[13,14]$. CrAlN advantages include good chemical stability at high temperatures and increased adhesion to the substrate. The other significant advantage over TiAlN is maximal possible ratio of metallic components $\mathrm{Cr}: \mathrm{Al}=30: 70$ while maintaining cubic structure. Further increasing of $\mathrm{Al}$ ratio leads to creation of more AIN phases negatively affecting physico-mechanical properties. High Al ratio also has a positive effect on oxidation resistance - it generates the protective $\mathrm{AlCrO}$ layer, which prevents further oxygen diffusion into the coating. So there are composition limits and possibilities of reaching higher oxidation resistance. From $700{ }^{\circ} \mathrm{C}$ to $800{ }^{\circ} \mathrm{C}$ the massive CrAlN layer oxidation occurs. Thanks to the protective $\mathrm{AlCrO}$ barrier, working temperatures may be higher.

One of the ways how to achieve higher oxidation resistance is using a multilayered system or nanocomposite layers. The CrAlSiN variant, with low chromium content around $6 \%$, has a high heat resistance. This layer composition prevents oxidation even at very high working temperatures. Multilayered system improves adhesion to a substrate and it reduces internal stress. This means that $\mathrm{CrAlN}$ or CrAlSiN coatings can be produced with thickness up to $10 \mu \mathrm{m}$, which is impossible for common PVD layers. With hardness HV values going over $35 \mathrm{GPa}$, these layers are matching TiAlN layers. It is assumed that both coating materials will complement each other in specific applications with high requirements 
on thermal and chemical stability. They are considered to be the layers of future.

TripleCoatings $^{3 \otimes}$ consist of conventional and nanocomposite coatings. They are deposited in three phases. The best adhesion is achieved by using titanium and/or chrome without using alloyed targets. Thanks to the similar Young's moduli the adhesive layer (TiN, CrN, CrTiN) allows a smooth transition between substrate and coating. Because of its low internal stress the middle layer provides a robust core with a good resistance to wear as well as superior hardness (AlTiN, AlTiCrN). The central cathode (position 4 in figure 1) ensures a high deposition rate, it means high productivity. The nanocomposite top layer shows an extremely high hardness and an excellent thermal isolation as well as a high resistance against abrasive wear [15].

The "universal" configuration of targets (position 1Ti, 2 - AlSi, $3-\mathrm{Cr}, 4-\mathrm{Al} / \mathrm{Ti}$ ), Fig. 1, offers the highest flexibility. More than 30 different coatings can be deposited without cathode exchange [7]. Current oxide, oxynitride and DLC (Diamond-Like-Carbon) coatings are based on an evolution of the TripleCoatings ${ }^{3 \circledR}$ principle $[16,17]$.

Aim of QuadCoatings ${ }^{4 \mathbb{B}}$ is integration of additional 4th feature e.g. extreme heat isolation with $\mathrm{AlON}$ or lubrication with $\mathrm{CrCN}$. Catode configuration for QUADCoatings $^{4 \circledR}$ is e.g. Ti-Al-TiSi-Al/Cr, or Ti-Al-Cr$\mathrm{Al} / \mathrm{Cr}$ [18]. Comparison of both types of coating is shown in Fig. 3.

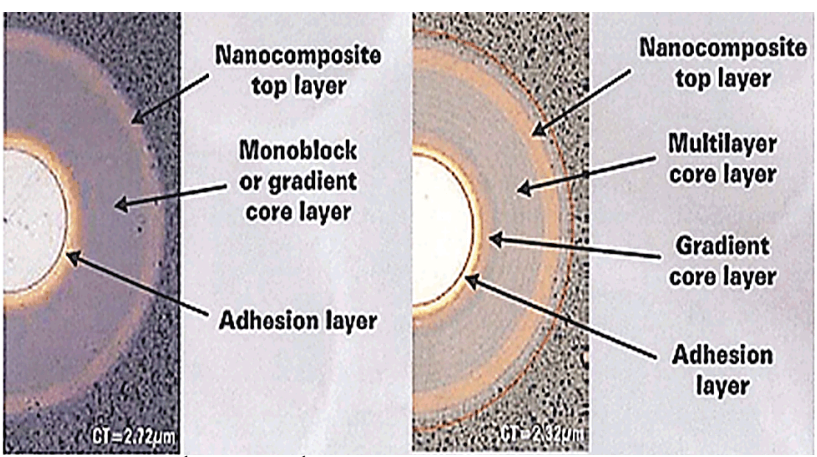

Figure 3 The $3^{\text {rd }}$ and the $4^{\text {th }}$ coating generations and their structures [18]

\section{Experimental techniques}

\subsection{Samples}

The primary physical properties of layers include hardness, thickness, roughness, adhesion and tribological properties. The most important chemical properties are oxidation resistance, chemical and thermal stability. The experiments examined three layer types applied on the fine grain cemented carbide substrate based on wolfram carbide with low cubic carbide content $(\mathrm{TaC}$ and $\mathrm{NbC}-$ $1,5 \%$ ) and with high bonding phase content (Co $10,2 \%$ ). Substrate hardness is $1310 \mathrm{HV}$, material density $14,5 \mathrm{~g} / \mathrm{cm}^{3}$ and toughness $1950 \mathrm{MPa}$. The tested coatings were applied on square tool inserts SPKN 1203EDER with length of cutting edge $12,7 \mathrm{~mm}$.

Sample No. 1: TiN + TiAlSiNnanocomposite + TiN, nanocomposite layer contains 22,3\% Ti, 14,6\% Al, 2,9 $\%$ Si (hardness $2600 \mathrm{HV}$, layer thickness 6,15 $\mu \mathrm{m}$ ).

Sample No. 2: TiN + TiAlNnanolayer + AlTiN, nanolayers contain $22,3 \% \mathrm{Ti}, 18,6 \% \mathrm{Al}$, top layer contains 26,2 \% Al and 13,2 \% Ti. (hardness $2908 \mathrm{HV}$, layer thickness $6,6 \mu \mathrm{m})$.

Sample No. 3: TiN + AlTiNnanolayer + TiN, nanolayers contain $21,8 \% \mathrm{Al}$ and $17,3 \% \mathrm{Ti}$ (hardness $3087 \mathrm{HV}$, layer thickness $8,75 \mu \mathrm{m})$.

\subsection{Layer hardness}

The hardness is defined as resistance of a material to deformation, indentation or penetration and it is the basic parameter characterizing wear resistant layers. Layer hardness can be measured only with load ensuring that the diamond indenter will penetrate layer maximally to $1 / 10$ of its thickness and the test results will not be affected by substrate properties. Special microhardness testers are the most frequently used equipment for this type of measurement. These testers can measure load and penetration depth of an indenter simultaneously, correct to units of nanometers [19].

To measure hardness, the $136^{\circ}$ pyramidal diamond indenter creating a square indent was used, loaded with $294,3 \mathrm{~N}$ for $10 \mathrm{~s}$. Hardness of sample 3 was the highest (3087 HV), the second highest sample 2 (2908 HV), and the lowest sample 1 (2600 HV). Nanolayered structure significantly increases hardness of samples 2 and 3 beside the monolayered sample 1 . These two nanolayers differ from each other by $\mathrm{Al}: \mathrm{Ti}$ ratio, whereas according to Paldey [20], increasing $\mathrm{Al}$ ratio in AlTiN layers improves their hardness, but only to $\mathrm{Ti}: \mathrm{Al}=40: 60 \%$. Higher $\mathrm{Al}$ ratio decreases layer hardness. The experiment results correspond to it, sample 3 with higher $\mathrm{Al}$ content in nanolayer structure with the ratio $\mathrm{Ti}: \mathrm{Al}=44,1: 55,9 \%$ has higher hardness than sample 2 with the ratio Ti:Al = 54,5:45,5\%.

\subsection{Layer thickness}

For machining applications, layer thickness on the cutting edge is one of the most important characteristics. It may affect not only tool durability, but also cutting forces. The optimal thickness varies according to the tool type, for screw-taps from 1 to $2 \mu \mathrm{m}$, for hobs up to $8 \mu \mathrm{m}$. Layer thickness on planar sections can be measured by method called calotest. Calotest uses the rotating sphere pressed on the coating surface in combination with abrasive slurry. Spherical cap is abraded into both the coating and the substrate. Thickness can be calculated on the basis of sphere diameter and measured diameters of spherical caps.

To measure thickness over the entire surface of cutting inserts, grinded cross section is used. In this case, thickness was measured on six spots of cutting insert cross section (in four corners plus in the middle of tool face and opposite surface - Fig. 4) to determine coating uniformity. The thickest coating was applied on sample 3 (edges $8,75 \mu \mathrm{m}$, planar surfaces $3,45 \mu \mathrm{m}$ ), the second thickest on sample 2 (edges $6,60 \mu \mathrm{m}$, planar surfaces 2,75 $\mu \mathrm{m}-$ Fig. 5) and the thinnest on sample 1 (edges $6,15 \mu \mathrm{m}$, planar surfaces $1,65 \mu \mathrm{m}$ ). Average thickness values on the edges and planar surfaces of tool face differ from average values of opposite surface maximally by $0,1 \mu \mathrm{m}$. The ratio between thickness on edges and planar surfaces is lowest on sample 2, so it has 
the most uniform coating. The second most uniform coating is on sample 3 and the highest ratio and the worse layer uniformity has sample 1 .

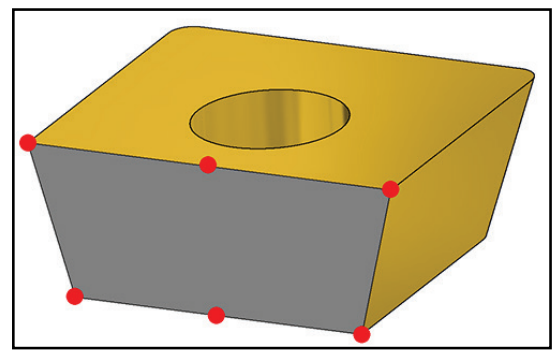

Figure 4 Places of thickness measurement
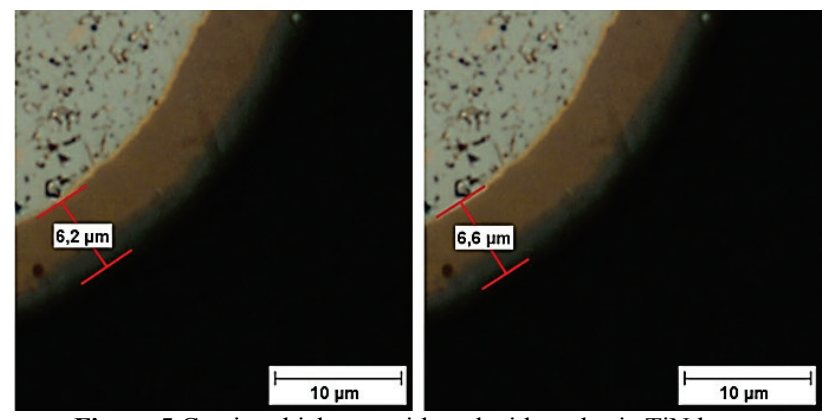

Figure 5 Coating thickness with and without basic TiN layers on sample 2 - cutting edge [12]

\section{Results and discussion of adhesion and tool life measurement \\ 3.1 Adhesion}

Maximizing the protective coating potential is possible only with its good adhesion to the substrate. Scratch-test is the standard method used for testing coating adhesion. The principle is drawing the diamond Rockwell indenter tip across the coated surface under incremental or progressive load. Considering common adhesion values, the load is usually from 20 to $120 \mathrm{~N}$. It is also possible to detect acoustic emission of the tip. Upon reaching a critical load, the coating will start to fail and separate from substrate and step increase in the value of acoustic emission will occur.

10.5 Sample $\mathrm{N}_{0.3}$

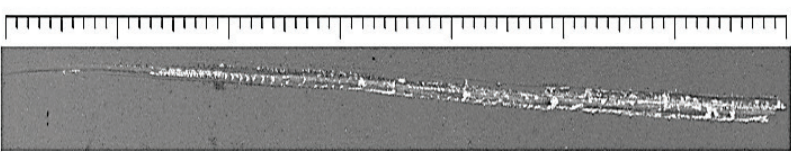

Sample No.2

59.

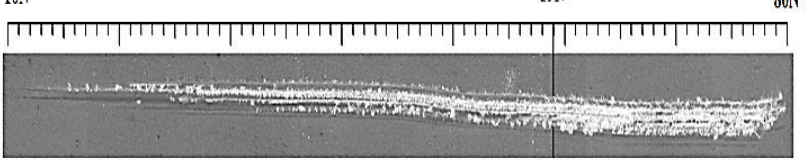

10. Sample $\mathrm{N}_{0.1}$

$67 \mathrm{~N} \quad 80 \mathrm{~N}$

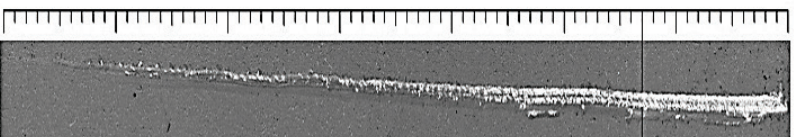

Figure 6 Results of scratch test
Evaluated samples were loaded with linearly increasing force from 10 to $80 \mathrm{~N}$. The chosen criterion for determining critical load is the start of peeling the entire width of scratch. The worst adhesion has sample 2 without upper TiN layer, peeling occurred at critical load of $59 \mathrm{~N}$. TiN is characterized by good adhesion properties14 and both samples with TiN upper layer have better adhesion. Sample 1 was measured to have a critical load of 67 N. Sample 3 has the best adhesion, peeling the entire width of scratch has not occurred - Fig. 6. It is caused by tougher nanolayered structure, which slows and diverts cracks.

\subsection{Tool life}

Experimental conditions are listed in Tab. 1. Flank wears $V B_{\mathrm{B}}=0,2 \mathrm{~mm}$ and $V B_{\mathrm{C}}=0,4 \mathrm{~mm}$ [22] were chosen as a criterion for durability evaluation. The results of experiments are shown in Tab. 2 and Fig. $7 \div 10$.

\begin{tabular}{|c|c|}
\multicolumn{2}{c}{ Table 1 Experimental conditions } \\
\begin{tabular}{|c|c|}
\hline Machine & Milling machine FCV 63 \\
\hline \multirow{2}{*}{ Cutting tool } & $\begin{array}{c}\text { Milling cutter 125B09R-W75SP12D, } \\
\text { diameter } 125 \mathrm{~mm}, \text { number of teeth }=9, \\
\kappa_{\mathrm{r}}=75^{\circ}, \gamma_{\mathrm{p}}=+7^{\circ}, \gamma_{\mathrm{f}}=0^{\circ}\end{array}$ \\
\hline Cutting insert & $\begin{array}{c}\text { SPKN } 1203 \mathrm{EDER} \\
l=12,7 \mathrm{~mm}, s=3,18 \mathrm{~mm}, m=0,95 \mathrm{~mm}\end{array}$ \\
\hline Work material & $\mathrm{C} 45,1.1191,100 \times 100 \times 800 \mathrm{~mm}$ \\
\hline Cutting conditions & $\begin{array}{c}v_{\mathrm{c}}=260 \mathrm{~m} / \mathrm{min}, f=0,2 \mathrm{~mm}, a_{\mathrm{p}}=2 \mathrm{~mm}, \\
a_{\mathrm{e}}=100 \mathrm{~mm}, \text { with coolant }\end{array}$ \\
\hline
\end{tabular}
\end{tabular}

\begin{tabular}{|c|c|c|c|c|}
\hline Sample & Test & $\begin{array}{l}\text { Durability } \\
\text { (min) }\end{array}$ & $\begin{array}{c}\text { Average } \\
\text { durability } \\
\text { (min) }\end{array}$ & $\begin{array}{c}\text { Productivity } \\
\%\end{array}$ \\
\hline \multirow{2}{*}{1} & 1 & 51,0 & \multirow{2}{*}{$52,5 \pm 1,52$} & \multirow{2}{*}{71} \\
\hline & 2 & 54,0 & & \\
\hline \multirow{2}{*}{2} & 1 & 72,0 & \multirow{2}{*}{$68,2 \pm 3,82$} & \multirow{2}{*}{92} \\
\hline & 2 & 64,4 & & \\
\hline \multirow{2}{*}{3} & 1 & 75,7 & \multirow{2}{*}{$74,3 \pm 1,49$} & \multirow{2}{*}{100} \\
\hline & 2 & 72,8 & & \\
\hline
\end{tabular}
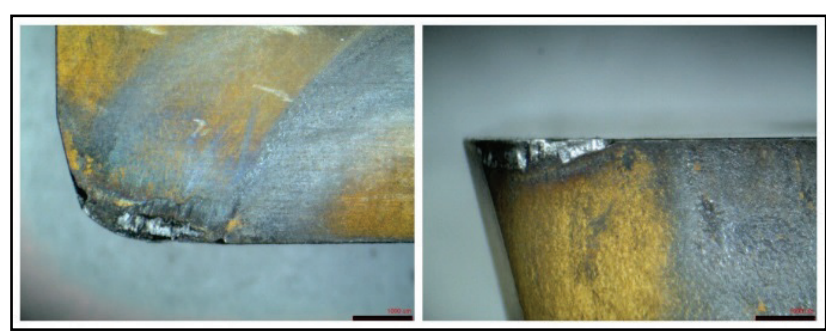

Figure 7 Wear of sample 1 after 60 minutes

During the initial phase of long-term test, the wear development of all samples was similar. At time around 40 minutes, the flank wear of samples 1 with nanocomposite rapidly increased and the average tool durability with this coating is 52,5 minutes. Nanocomposite structure and the lowest thickness are the main reasons of shorter tool life.

Flank wear was chosen as a criterion for durability evaluation. This wear type is characterized by abrasion, which depends on tool material hardness. Samples 2 have upper AlTiN layer containing $\mathrm{Al}$, which increases hardness. But its structure consisting of TiAlNnanolayer has lower hardness due to lower $\mathrm{Al}$ ratio. The most 
durable are samples 3 with upper TiN layer and higher $\mathrm{Al}$ content in nanolayered structure. Results were also affected by a coating thickness and nanocomposite structure thickness itself.

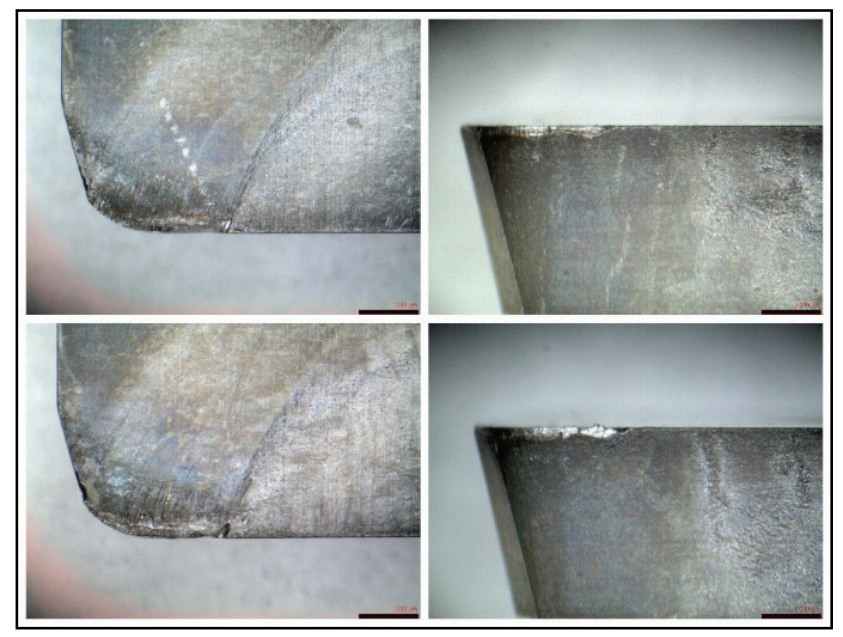

Figure 8 Wear of sample 2 after 60 minutes (up) and after 72 minutes (down)

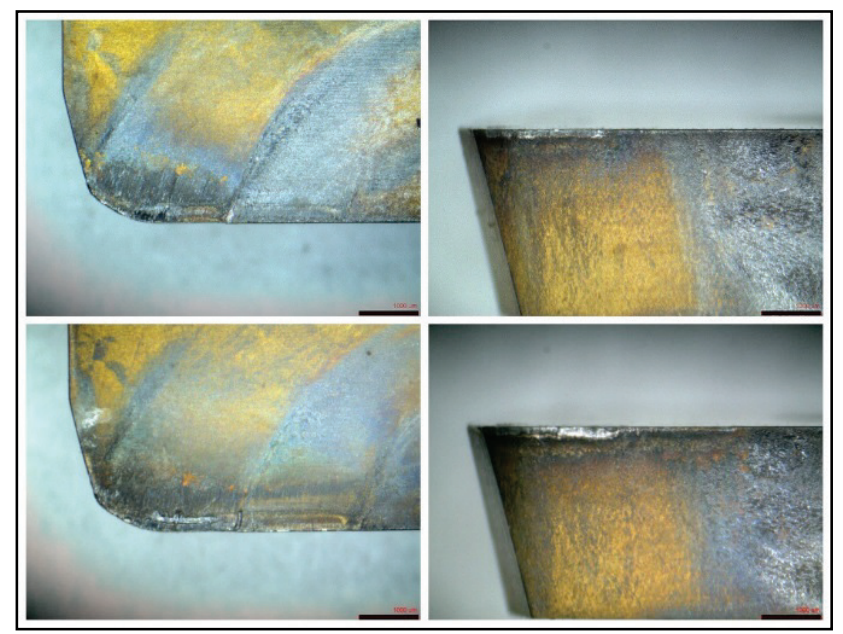

Figure 9 Wear of sample 3 after 60 minutes (up) and after 78 minutes (down)

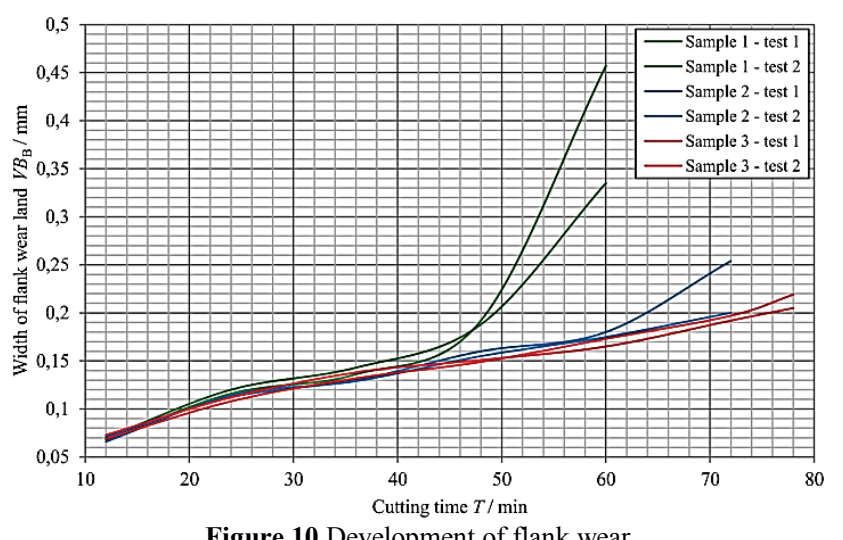

\section{Conclusion}

From the previous overview of modern coatings it is evident that the top PVD coating manufacturers are able to produce coatings for any application. In case of cutting tools, performance is affected not only by protective coating, but also by cutting geometry, substrate material and machining parameters, such as cutting conditions.

Aim of the paper was to compare some properties of three different PVD coatings with nanocomposite and nanolayer structure.

- Regarding layer hardness, hardness of sample 3 was the highest (3087 HV), the second highest was sample 2 (2908 HV), and the lowest was sample 1 (2600 HV). Structure of nanolayers significantly increases hardness of samples 2 and 3 beside the nanocomposite sample 1 . These two nanolayers differ from each other by Al:Ti ratio, whereas increasing $\mathrm{Al}$ ratio in AlTiN layers improves their hardness, but only to $\mathrm{Ti}: \mathrm{Al}=40: 60 \%$. Higher $\mathrm{Al}$ ratio decreases layer hardness. The experiment results correspond to this, sample 3 with higher $\mathrm{Al}$ content in nanolayer structure with the ratio Ti:Al $=44,1: 55,9 \%$ has higher hardness than sample 2 with the ratio $\mathrm{Ti}: \mathrm{Al}$ $=54,5: 45,5 \%$.

- Regarding layer thickness, thickness was measured on six spots of cutting insert cross section (in four corners plus in the middle of tool face and opposite surface) to determine coating uniformity. The thickest coating was applied on sample 3, the second thickest on sample 2 and the thinnest on sample 1. Average thickness values on the edges and planar surfaces of tool face differ from average values of opposite surface maximally by $0,1 \mu \mathrm{m}$. The ratio between thickness on edges and planar surfaces is lowest on sample 2, so it has the most uniform coating. The second most uniform coating is on sample 3 and the highest ratio and the worse layer uniformity has sample 1.

- Results of adhesion test are listed in Fig. 6 in Chapter 3.1. The best adhesion has been shown by sample 3 with nanolayer structure AlTiN.

- Regarding long-term test, nanolayer coatings are tougher than nanocomposite layer. By milling longterm test it is possible to achieve better results. Flank wear was chosen as a criterion for durability, abrasion is the predominant mechanism of wear. Surface of sample 2 is formed by AlTiN, which has higher hardness than TiN. On the other hand the hardness of nanolayers TiAlN is - owing to lesser representation of $\mathrm{Al}$ in structure - smaller than the hardness of nanolayers of sample 3 . This sample has $\mathrm{Ti} / \mathrm{Al}$ ratio of $44,1 / 55,9 \%$. Sample 3 has shown the highest hardness of all tested samples. The results were also influenced by thickness of nanolayers and all coating which has this sample the biggest.

\section{Aknowledgement}

This article was written with the financial support of the MŠMT ČR (SGS project no. SP2013/98 - Productive Machining of Materials and No. SP2014/105 Productive and Environmental Machining of Materials).

\section{References}

[1] Krolczyk, G. M.; Nieslony, P.; Legutko, S. Determination of tool life and research wear during duplex stainless steel 
turning. // Achieves of Civil and Mechanical Engineering. 15, (2015), pp. 347-354. DOI: 10.1016/j.acme.2014.05.001

[2] Krolczyk, G. M.; Legutko, S. Investigations into surface integrity in the turning process. // Transaction of FAMENA. 38, 2(2014), pp. 77-82.

[3] Krolczyk, G. M.; Legutko, S. Experimental analysis by measurement of surface roughness variations in turning process of duplex stainless steel. // Metrology and Measurement Systems. 21, 4(2014), pp. 759-770. DOl: 10.2478/mms-2014-0060

[4] Krolczyk, G. M.; Legutko, S.; Raos, P. Cutting wedge wear examination during turning of duplex stainless steel. // Tehnički Vjesnik-Technical Gazette. 20, 3(2013), pp. 413418.

[5] Krolczyk, G. M.; Gajek, M.; Legutko, S. Effect of the cutting parameters impact onto tool life in duplex stainless steel turning process. // TehničkiVjesnik-Technical Gazette. 20, 4(2013), pp. 587-592.

[6] Humár, A. Cutting Tool Materials, MM publishing, s.r.o., Praha, 2008.

[7] Cselle, T. Compendium 2011, Grenchen: Platit AG, 2011.

[8] Cselle, T. New coating for rotated tool, VDI-Z Special Werkzeuge, 8, (1999), pp. 38-42.

[9] Cselle, T. With coating technology to increase. // Werkstatt und Betrieb. 137, 5(2004), pp. 84-88.

[10] Cselle, T. Inhouse-coating versus pay-coating. // Werkstatt und Betrieb. 138, 6(2005), pp. 22-26.

[11] Fromme, M.; Arndt, M. High-efficiency coats for precise tools. // Werkstatt und Betrieb. 138, 6(2005), pp. 20-21.

[12] Holubář, P.; Jílek, M.; Růžička, M. Modern PVD coatings for cutting applications and working. // MM Průmyslovéspectrum. 9, (2004), pp. 106-107.

[13] Kraus, J. PVD-coating for separate of hard oxide coats (in German). // MM Industriemagazin-Maschinenmarkt. 1, 2(2007), pp. 32.

[14] Peyerl, G. PVD-coatings on AlCrN base increase tool productivity, MM Industriemagazin-Maschinenmarkt, 31/32, (2010), pp. 37.

[15] Cselle, T. Adapt to use. // Werkstatt und Betrieb. 142, 11(2009), pp. 30-34.

[16] Cselle, T. et al. Dedication - Integration - Open Source New Rules in the Coating Industry (and in progressive economics). // Werkzeug Technik. 120b, (2011), pp. 22-29.

[17] Píška, M. Trends in PVD and CVD coating. // MM Průmyslovéspectrum. 11/supplement, (2014), pp. VIII-IX.

[18] Cselle, T. Compendium 2014, Grenchen: Platit AG, 2014.

[19] Krolczyk, G. M.; Nieslony, P.; Legutko, S. Microhardness and surface integrity in turning process of duplex stainless steel (DSS) for different cutting conditions. // Journal of Materials Engineering and Performance. 23, 3(2014), pp. 859-866. DOI: $10.1007 / \mathrm{s} 11665-013-0832-4$

[20] Padley, S.; Deevi, S. C. Single layer and multilayer wear resistant coatings of $(\mathrm{Ti}, \mathrm{Al}) \mathrm{N}$ : a review. // Materials Science and Engineering: A. 342, (2003), pp. 58-79. DOl: 10.1016/S0921-5093(02)00259-9

[21] Sléha, V. Application Area of PVD Coatings by Cutting Tools From Cemented Carbide, Bachelor Thesis, Ostrava: VSB - Technical university of Ostrava, Faculty of Mechanical Engineering, Department of Working and Assembly, 2013.

[22] ISO 3685.Tool-life testing with single-point turning tools. International Organization for Standardization, Geneve, 1993.

\section{Authors' addresses}

Mrkvica Ivan, Assoc. Prof., Ph.D., MSc.

VŠB-Technical University of Ostrava

Faculty of Mechanical Engineering Department of Machining and Assembly

17. listopadu 15/2172, 70833 Ostrava, Czech Republic

E-mail: ivan.mrkvica@vsb.cz

Neslušan Miroslav, Prof., Ph.D., MSc.

Zilina University in Zilina

Faculty of Mechanical Engineering

Department of Machining and Manufacturing

TechnologisUniverzitna 1, 01026 Žilina, Slovakia

E-mail: miroslav.neslusan@fstroj.uniza.sk

Čep Robert, Assoc. Prof., Ph.D., MSc.

VSSB-Technical University of Ostrava

Faculty of Mechanical Engineering

Department of Machining and Assembly

17. listopadu 15/2172, 70833 Ostrava, Czech Republic

E-mail: robert.cep@vsb.cz

Sléha Vojtěch

VŠB-Technical University of Ostrava

Faculty of Mechanical Engineering

Department of Machining and Assembly

17. listopadu 15/2172, 70833 Ostrava, Czech Republic

E-mail: vojtech.sleha.st@vsb.cz 